\title{
Antiprotozoal Alkaloids from Psychotria prunifolia (Kunth) Steyerm
}

\author{
Lucilia Kato, ${ }^{*, a}$ Cecília M. A. de Oliveira ${ }^{a}$ Emiret O. Faria, ${ }^{a}$ Laryssa C. Ribeiro, ${ }^{a}$ \\ Brenda G. Carvalho, ${ }^{a}$ Cleuza C. da Silva, ${ }^{b}$ Ivânia T. A. Schuquel, ${ }^{b}$ Silvana M. O. Santin, ${ }^{b}$ \\ Celso V. Nakamura, ${ }^{c}$ Elisandra A. Britta, ${ }^{c}$ Nathielle Miranda, ${ }^{c}$ Amadeu H. Iglesias ${ }^{d}$ and \\ Piero G. Delprete
}

${ }^{a}$ Instituto de Química, Universidade Federal de Goiás, Campus II, Samambaia, 74001-970 Goiânia-GO, Brazil

${ }^{b}$ Departamento de Química and ${ }^{c}$ Departamento de Farmácia e Farmacologia, Universidade Estadual de Maringá, Av. Colombo, 5790, 87020-900 Maringá-PR, Brazil

${ }^{d}$ Waters Technologies do Brasil LTDA, 125 /27, Alphaville, 06455-020 Barueri-SP, Brazil

${ }^{e}$ Herbier de Guyane, Institut de Recherche pour le Développement (IRD), UMR AMAP, B.P. 165, 97323 Cayenne Cedex, French Guiana, France

\begin{abstract}
A continuidade do estudo fitoquímico de $P$. prunifolia com a análise dos extratos etanólicos obtidos a partir de suas raízes e galhos levou ao isolamento de cinco alcaloides indol- $\beta$-carbolínicos dos quais, dois derivados, o 10-hidróxi-iso-deppeaninol e o N-óxido-10-hidróxi-antirhina são descritos pela primeira vez. As estruturas foram determinadas por análise de técnicas espectroscópicas de IV, EMAR e RMN ( ${ }^{1} \mathrm{H}$ e ${ }^{13} \mathrm{C}, 1 \mathrm{D}$ e 2D). A avaliação da atividade frente à Leishmania amazonensis e Trypanosoma cruzi, mostrou que os extratos brutos e os alcaloides 14-oxoprunifoleína e estrictosamida inibiram as formas promastigotas de L. amazonensis, com valores de $\mathrm{CI}_{50}$ de 16,0 e 40,7 $\mu \mathrm{g}$ per $\mathrm{mL}$, respectivamente.
\end{abstract}

The continuity of the phytochemical study of crude extracts of $P$. prunifolia's roots and branches led to the isolation of five indole- $\beta$-carboline alkaloids. Among them, the 10-hydroxyiso-deppeaninol and N-oxide-10-hydroxy-antirhine derivatives are described here for the first time. The structures were achieved through 1D and 2D NMR, IR and HRMS analyses. The branches and roots crude extracts and the alkaloids 14-oxoprunifoleine and strictosamide showed selective activity against $L$. amazonensis, with $\mathrm{IC}_{50}$ values of 16.0 and $40.7 \mu \mathrm{g}$ per $\mathrm{mL}$, respectively.

Keywords: $\beta$-carboline alkaloids, antiprotozoal, Trypanosoma, Leishmania, Psychotria prunifolia, Rubiaceae

\section{Introduction}

The genus Psychotria, one of the largest genera of the Rubiaceae, has a long history of indigenous use as a component of the hallucinogenic beverage ayahuasca and also in traditional medicines used to treat microbial infections, inflammatory disease and complications of pregnancy. Pharmacological studies of Psychotria species, such as $P$. umbelata Tonn, P. leiocarpa Cham. $\&$ Schltdl, and $P$. insularum A. Gray revealed that their crude extracts possessed analgesic and allelophatic

*e-mail: lucilia@quimica.ufg.br properties, as well as depressed the central nervous system and decreased the inflammatory action of cyclooxygenase..$^{1-5}$

P. prunifolia is an understory shrub ranging from Venezuela, throughout the Amazon basin, to Bolivia and southern Brazil, with its southern limit in the state of São Paulo. Previous phytochemical studies carried out on several species of Psychotria have resulted in the identification of polypyrrolidine indole, monoterpenoid indole, and isoquinoline alkaloids..$^{6-8}$ In our laboratory, phytochemical study of the leaves of $P$. prunifolia collected in Brazilian Cerrado have led to the isolation of $\beta$-carboline alkaloids and triterpenes. ${ }^{9}$ 
Numerous reports in the current literature provide evidence that alkaloids possessing an indole moiety could display important antiprotozoal activities. For example, alkaloids like harmane have exerted antiproliferative effects toward parasites of the genus Trypanosoma. ${ }^{10,11}$ The bis-indole alkaloids ramiflorines A and B isolated from Aspidosperma ramiflorum exhibited remarkable activity in in vitro assays against promastigote forms of L. amazonensis. ${ }^{12}$ In addition, indole alkaloids isolated from the bark of Corynanthe pachyceras (Rubiaceae) and Kopsia griffithii (Apocynaceae) showed activity against promastigotes of L. major and L. donavani. ${ }^{13,14}$

In this study, further phytochemical work was performed on $P$. prunifolia with particular attention to their alkaloid constituents, resulting in the isolation of two new beta carboline derivatives ( $\mathbf{1}$ and $\mathbf{3}$ ), besides the three known compounds $\mathbf{2}, \mathbf{4}$, and $\mathbf{5}$. Here we report the structural determination of the new alkaloids and the antiprotozoal activity of the crude extracts of $P$. prunifolia and the major alkaloids $\mathbf{4}$ and $\mathbf{5}$.

\section{Results and Discussion}

\section{Structural elucidation of new alkaloids}

Alkaloid $1[\alpha]^{25}=-21.5^{\circ}(\mathrm{MeOH}, c=0.085)$ was obtained as a yellowish oil and was positive with Dragendorff's reagent. Analysis of HRMS data indicated that compound $\mathbf{1}$ had the molecular formula $\mathrm{C}_{19} \mathrm{H}_{22} \mathrm{~N}_{2} \mathrm{O}_{3}$ $\left(\mathrm{m} / \mathrm{z}\right.$ 326.1630), $\left[(\mathrm{M}+\mathrm{H})^{+}\right.$observed at $\mathrm{m} / \mathrm{z} 327.1693$, calculated 327.1709, $\left.\mathrm{C}_{19} \mathrm{H}_{23} \mathrm{~N}_{2} \mathrm{O}_{3}\right]$.

The ${ }^{1} \mathrm{H}(1 \mathrm{D}$ and $2 \mathrm{D} \mathrm{COSY}),{ }^{13} \mathrm{C}\left(\left\{{ }^{1} \mathrm{H}\right\}\right.$, DEPT $90^{\circ}$ and DEPT $\left.135^{\circ}\right)$, HMQC and HMBC NMR spectra revealed the presence of four $\mathrm{sp}^{3}$ methylene units (two of which were oxygenated), two olefinic carbons in a vinyl group, five aromatic and two aliphatic methines, and six $\mathrm{sp}^{2}$ quaternary carbons. A 1,2,4-trisubstituted aromatic and 1,2,3 trisubstituted-pyridine ring were present in the structure, as evidenced by signals at $\delta_{\mathrm{H}} 7.42(\mathrm{~d}, J 2.4 \mathrm{~Hz}, \mathrm{H}-9), 7.36$ (d, $J 9.0 \mathrm{~Hz}, \mathrm{H}-12), 7.05$ (dd, $J 9.0,2.4 \mathrm{~Hz}, \mathrm{H}-11$ ), and at $\delta_{\mathrm{H}} 8.06(\mathrm{~d}, J 5.4 \mathrm{~Hz}, \mathrm{H}-5)$ and $7.84(\mathrm{~d}, J 5.4 \mathrm{~Hz}, \mathrm{H}-6)$ correlated to $\delta_{\mathrm{C}} 106.6,113.7,120.4,135.7$ and 114.6 in the HMQC spectra, respectively. HMBC correlations among H-6/C-8 $\left(\delta_{\mathrm{C}} 123.1\right)$ and $\mathrm{C}-2\left(\delta_{\mathrm{C}} 136.9\right)$, together with the correlation observed for H-5/C-3 $\left(\delta_{\mathrm{C}} 145.5\right)$ and C-7 $\left(\delta_{\mathrm{C}} 130.6\right)$, helped us to assign the presence of an indole $\beta$-carboline moiety substituted in position 10 or 11 by a hydroxyl group. The ${ }^{3} J \mathrm{HMBC}$ correlation $\mathrm{H}-11 / \mathrm{C}-13\left(\delta_{\mathrm{C}} 137.5\right)$, in addition to the NOE correlation between $\mathrm{H}-6 / \mathrm{H}-9$ and the coupling pattern from aromatic protons with $J_{\mathrm{H} 9 \mathrm{H} 11} 2.4$ and $J_{\mathrm{H} 1-\mathrm{H} 12} 9.0 \mathrm{~Hz}$, corroborated the hydroxyl at $\mathrm{C}-10\left(\delta_{\mathrm{C}} 152.6\right)$.
Apart from the indole $\beta$-carboline ring, the spectral data (HMQC and ${ }^{13} \mathrm{C}$ ) showed two methine groups at $\delta_{\mathrm{C}} 36.4$ and 51.0, two oxygenated methylenes $\left(\delta_{\mathrm{C}} 61.4\right.$ and 64.4), and one vinyl portion at $\delta_{\mathrm{C}} 118.7$ (methylene) and 138.1 (methine). Information from COSY and HMQC data showed spin systems ranging for $\mathrm{H}-14 / \mathrm{H}-$ 15/H-16/H-17, H-15/H-20/H-21, and H-18/H-19/H-20. The ${ }^{2} J$ HMBC correlation observed between H-14/C-3 and ${ }^{3} J$ observed for $\mathrm{H}-14 / \mathrm{C}-16$ and $\mathrm{H}-14 / \mathrm{C}-20$ permitted us to suggest the connection between the aliphatic unit and the indolic $\beta$-carboline unit (Figure 1). Further HMBC correlations are described in Table 1. All these data were consistent with a new alkaloid similar to 10-hydroxy derivative of deppeaninol, which was assigned as alkaloid 1 identified as 10-hydroxy-iso-deppeaninol. The relative configuration proposed is that observed of corynantheineheteroyohimbine alkaloids. Deppeaninol was isolated from Deppea blumenaviensis (Rubiaceae) and described by Kan-Fan et al. ${ }^{15}$

Alkaloid 2 was obtained as a brownish oil and was positive to Dragendorff's reagent. Its molecular formula was determined by HRMS, which exhibited a molecular ion $[\mathrm{M}+\mathrm{H}]^{+}$observed at $\mathrm{m} / \mathrm{z} 313.1920$ (calculated $\mathrm{m} / \mathrm{z}$ 313.1916, $\mathrm{C}_{19} \mathrm{H}_{25} \mathrm{~N}_{2} \mathrm{O}_{2}$ ) consistent with a molecular formula of $\mathrm{C}_{19} \mathrm{H}_{24} \mathrm{~N}_{2} \mathrm{O}_{2}(m / z 312.1838)$. The ${ }^{1} \mathrm{H}$ (1D and 2D COSY), ${ }^{13} \mathrm{C}\left(\left\{{ }^{1} \mathrm{H}\right\}\right.$, DEPT $90^{\circ}$ and DEPT $\left.135^{\circ}\right), \mathrm{HMQC}$ and HMBC NMR spectra data showed the presence of six $\mathrm{sp}^{3}$ methylene units (one of which was oxygenated), two olefinic carbons (one of which was a methylene unit), three aromatic and three aliphatic methines, and five $\mathrm{sp}^{2}$ quaternary carbons. The resonances and the ${ }^{1} \mathrm{H}$ NMR $J$ values at $\delta_{\mathrm{H}} 6.80(\mathrm{~d}$, $J 2.4 \mathrm{~Hz}), 6.68(\mathrm{dd}, J 8.7$ and $2.4 \mathrm{~Hz}$ ) and $7.17(\mathrm{~d}, J 8.7 \mathrm{~Hz})$ were attributed to a trisubstituted aromatic system with a 10 or 11 -substitution pattern.

In addition to these assignments, the HMBC correlations from $\mathrm{H}-5 \mathrm{a}\left(\delta_{\mathrm{H}} 3.57, \mathrm{dd}, J 12.6\right.$ and $\left.6.0 \mathrm{~Hz}\right)$ to $\mathrm{C}-7\left(\delta_{\mathrm{C}} 106.0\right)$ and from $\mathrm{H}-6 \mathrm{a}\left(\delta_{\mathrm{H}} 2.82, \mathrm{dd}, J 16.2\right.$ and $\left.4.8 \mathrm{~Hz}\right)$ and $\mathrm{H}-6 \mathrm{~b}$ $\left(\delta_{\mathrm{H}} 3.01, m\right)$ to $\mathrm{C}-7\left(\delta_{\mathrm{C}} 106.0\right)$ and $\mathrm{C}-2\left(\delta_{\mathrm{C}} 130.5\right)$ indicated the presence of a tetrahydro- $\beta$-carboline moiety in the structure of alkaloid 2.

Analysis of COSY data indicated proton spin systems corresponding to $\mathrm{H}-16 / \mathrm{H}-17, \mathrm{H}-3 / \mathrm{H}-14 / \mathrm{H}-15$ and $\mathrm{H}-18 / \mathrm{H}-$ 19/H-20/H-21, suggesting a cyclic terpene scaffold. HMBC correlations from $\mathrm{H}-18$ to C-20 and $\mathrm{H}-21$ to $\mathrm{C}-20 / \mathrm{C}-15$ further revealed the connectivities in the terpene unit. The ${ }^{3} J$ HMBC correlations among H-6 to C-2, H-5 to C-17 and $\mathrm{H}-14$ to $\mathrm{C}-2$ led to the direct connection of the indole and terpene moieties. All of these assignments, combined with the literature data, permitted us to identify alkaloid $\mathbf{2}$ as 10-hydroxy-antirhine, which was previously isolated from Ochrosia alyxiodis. ${ }^{16}$ 


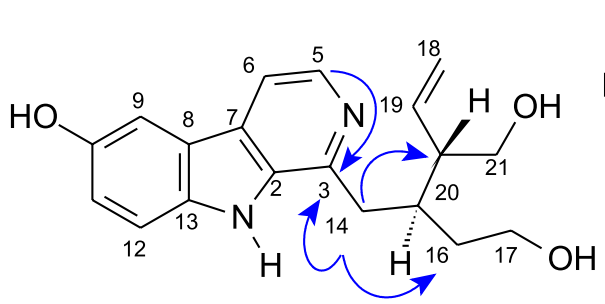

1

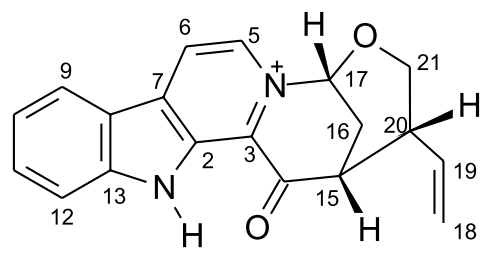

4

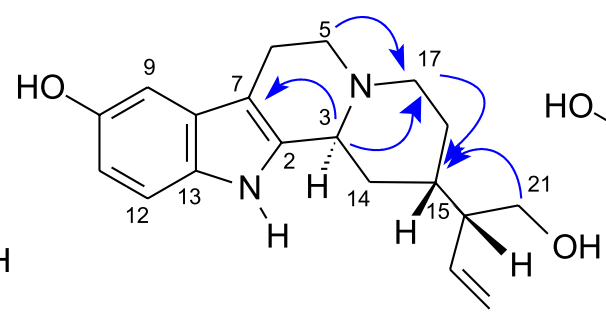

2

18

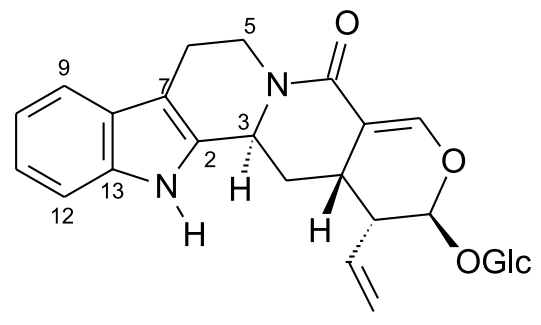

5

Figure 1. Alkaloids $\mathbf{1}$ through $\mathbf{5}$ isolated from P. prunifolia and the main HBMC correlations observed for alkaloids 1-3.

Table 1. ${ }^{1} \mathrm{H}(300 \mathrm{MHz})$ and ${ }^{13} \mathrm{C}(75 \mathrm{MHz}) * \mathrm{NMR}$ data for alkaloid 1 in $\mathrm{CD}_{3} \mathrm{OD}$ with TMS used as internal standard

\begin{tabular}{|c|c|c|c|c|}
\hline $\mathrm{C}$ & $\delta{ }^{13} \mathrm{C}$ & $\delta{ }^{1} \mathrm{H}$ (mult, $\mathrm{nH}, J$ in $\left.\mathrm{Hz}\right)$ & ${ }^{1} \mathrm{H} 2 \mathrm{D} \operatorname{COSY}$ & ${ }^{1} \mathrm{H},{ }^{13} \mathrm{C}$ HMBC \\
\hline 2 & 136.9 & - & - & - \\
\hline 3 & 145.5 & - & - & - \\
\hline 5 & 135.7 & $8.06(\mathrm{~d}, 1 \mathrm{H}, 5.4)$ & H-6 & $\mathrm{C}-6, \mathrm{C}-3, \mathrm{C}-7$. \\
\hline 6 & 114.6 & $7.84(\mathrm{~d}, 1 \mathrm{H}, 5.4)$ & $\mathrm{H}-5$ & $\mathrm{C}-8, \mathrm{C}-2$ \\
\hline 7 & 130.6 & - & - & - \\
\hline 8 & 123.1 & - & - & - \\
\hline 9 & 106.6 & $7.42(\mathrm{~d}, 1 \mathrm{H}, 2.4)$ & $\mathrm{H}-11$ & C-11, C-10, C-13, C-7 \\
\hline 10 & 152.6 & - & - & - \\
\hline 11 & 120.4 & $7.05(\mathrm{dd}, 1 \mathrm{H}, 9.0$ and 2.4$)$ & $\mathrm{H}-9, \mathrm{H}-12$ & C-9, C-13 \\
\hline 12 & 113.7 & $7.36(\mathrm{~d}, 1 \mathrm{H}, 9.0)$ & $\mathrm{H}-11$ & $\mathrm{C}-8, \mathrm{C}-10$ \\
\hline 13 & 137.5 & - & - & - \\
\hline 14 & 37.0 & $3.10(\mathrm{~d}, 2 \mathrm{H}, 7.2)$ & $\mathrm{H}-15$ & C-3, C-2, C-20, C-15, C-16 \\
\hline 15 & 36.4 & $2.44(\mathrm{~m}, 1 \mathrm{H})$ & H-14, H-20, H-16 & \\
\hline $16 \mathrm{a}$ & 34.0 & $1.40(\mathrm{~m}, 1 \mathrm{H})$ & H-16b, H-17 & C-17, C-15 \\
\hline $16 \mathrm{~b}$ & & $1.70(\mathrm{~m}, 1 \mathrm{H})$ & H-16a, H-15, H-17 & \\
\hline 17 & 61.4 & $3.38(\mathrm{~m}, 1 \mathrm{H})$ & $1.80(\mathrm{H}-16), 1.49(\mathrm{H}-16)$ & \\
\hline 18 & 118.7 & $\begin{array}{l}5.07(\mathrm{dd}, 1 \mathrm{H}, 10.2,1.8) \\
5.02(\mathrm{dd}, 1 \mathrm{H}, 17.1,1.8)\end{array}$ & $\begin{array}{l}5.08,5.83(\mathrm{H}-19) \\
5.19,5.83(\mathrm{H}-19)\end{array}$ & $\begin{array}{l}\mathrm{C}-19 \mathrm{C}-20 \\
\mathrm{C}-20\end{array}$ \\
\hline 19 & 138.1 & $5.74(\mathrm{ddd}, 1 \mathrm{H}, 17.1,10.2,9.0)$ & $5.08(\mathrm{H}-18 E), 5.19(\mathrm{H}-18 Z), 2.26(\mathrm{H}-20)$ & \\
\hline 20 & 51.0 & $2.17(\mathrm{~m}, 1 \mathrm{H})$ & $5.83(\mathrm{H}-19), 3.61(\mathrm{H}-21), 2.53(\mathrm{H}-15)$ & \\
\hline 21 & 64.4 & $3.52(\mathrm{~d}, 2 \mathrm{H}, 6.6)$ & $2.26(\mathrm{H}-20)$ & C-19, C-20, C-15 \\
\hline
\end{tabular}

Reported as chemical shifts $(\delta, \mathrm{ppm}) ;{ }^{*}$ Number of hydrogens bound to carbon atoms deduced by comparative analyses of $\left\{{ }^{1} \mathrm{H}\right\}-$ and DEPT- ${ }^{13} \mathrm{C}$ NMR spectra.

Alkaloid $3(6.2 \mathrm{mg})[\alpha]^{25}=+108.2^{\circ}(\mathrm{MeOH}, c=0.135)$ was isolated as a brown oil and was also positive with Dragendorff's reagent. The HR ESI-MS exhibited a quasi- molecular $[\mathrm{M}-\mathrm{H}]^{-}$ion peak at $\mathrm{m} / \mathrm{z}, 327.1712$, (calculated 327.1709, $\mathrm{C}_{19} \mathrm{H}_{23} \mathrm{~N}_{2} \mathrm{O}_{3}$ ) consistent with the molecular formula $\mathrm{C}_{19} \mathrm{H}_{24} \mathrm{~N}_{2} \mathrm{O}_{3} \cdot(\mathrm{m} / \mathrm{z} 328.1787)$. This ion was $16 \mathrm{amu}$ 
higher than that of compound 2, which is typical for $\mathrm{N}$-oxide derivatives.

The signals at $\delta_{\mathrm{H}} 6.71(\mathrm{~d}, J 2.1 \mathrm{~Hz}, \mathrm{H}-9), 6.60(\mathrm{dd}$, $J 8.7$ and $2.1 \mathrm{~Hz}, \mathrm{H}-11)$ and $7.08(\mathrm{~d}, J 8.7 \mathrm{~Hz})$ suggest the same pattern of aromatic moiety. In the COSY spectra could be identified spin systems of $\mathrm{H}-9 / \mathrm{H}-11 / \mathrm{H}-12$, H-5/H-6, H-3/H-14, H-16/H-17 and H-18/H-19. The HMBC experiment showed correlation among H-5/C-17, H-6/C-2, H-14/C-2/C-3/C-15, H-16/C-15, H-18/C-20 and H-21/C-15/C-20, establishing a connection between the terpene and indole units. The analysis of all the spectral data suggested that $\mathbf{3}$ possessed the same skeleton of $\mathbf{2}$, but with differences in the chemical shifts at the carbons $\mathrm{C}-3$, C-5 and C-17 of $\Delta \delta+14.6,+16.6$ and +11.1 , respectively. This deshielding effect observed in the ${ }^{13} \mathrm{C}$ could be attributed to the influence of an $\mathrm{N}$-oxide at the $\mathrm{N}-4$ position and permitted us to assign alkaloid $\mathbf{3}$ as a 10 -hydroxyantirhine $\mathrm{N}$-oxide derivative. The alkaloids $\mathbf{4}$ and $\mathbf{5}$ were isolated previously ${ }^{9}$ and identified as 14-oxoprunifoleine and strictosamide, respectively.

\section{Antiprotozoal assay}

In this study, the crude extracts of roots and branches and the major alkaloids $\mathbf{4}$ and $\mathbf{5}$ were evaluated for in vitro antiprotozoal activity against promastigotes of Leishmania amazonensis and epimastigotes of Trypanosoma cruzi strains. Table 3 summarises the antiprotozoal activity data for the ethanolic crude extracts and the known alkaloids (4 and 5). In both cases, L. amazonensis was the most sensitive protozoan. The ethanolic root extract was the most active among the extracts assayed. For comparison, the two

Table 2. ${ }^{1} \mathrm{H}(300 \mathrm{MHz})$ and ${ }^{13} \mathrm{C}(75 \mathrm{MHz}) *$ NMR data for alkaloid 2 and $\mathbf{3}$ in $\mathrm{CD}_{3} \mathrm{OD}$ with TMS used as internal standard

\begin{tabular}{|c|c|c|c|c|}
\hline \multirow[t]{2}{*}{$\mathrm{C}$} & \multicolumn{2}{|r|}{2} & \multicolumn{2}{|r|}{3} \\
\hline & $\delta{ }^{13} \mathrm{C}$ & $\delta{ }^{1} \mathrm{H}$ (mult, $\mathrm{nH}, J$ in $\left.\mathrm{Hz}\right)$ & $\delta{ }^{13} \mathrm{C}$ & $\delta{ }^{1} \mathrm{H}$ (mult, $\mathrm{nH}, J$ in $\left.\mathrm{Hz}\right)$ \\
\hline 2 & 130.5 & - & 131.0 & - \\
\hline 3 & 57.0 & $4.72(\mathrm{~s} \mathrm{br}, 1 \mathrm{H})$ & 71.6 & $4.58(\mathrm{~s} \mathrm{br}, 1 \mathrm{H})$ \\
\hline \multirow[t]{2}{*}{5} & 52.4 & $3.57(\mathrm{dd}, 1 \mathrm{H}, 12.6$ and 6.0$)$ & 69.0 & $3.66(\mathrm{~m}, 2 \mathrm{H})$ \\
\hline & & $3.41(\mathrm{~m}, 1 \mathrm{H})$ & & $3.50(\mathrm{~m}, 1 \mathrm{H})$ \\
\hline \multirow[t]{2}{*}{6} & 18.1 & $2.82(\mathrm{dd}, 1 \mathrm{H}, 16.2,4.8)$ & 20.6 & $3.03-2.92(\mathrm{~m}, 2 \mathrm{H})$ \\
\hline & & $3.01(\mathrm{~m}, 1 \mathrm{H})$ & & \\
\hline 7 & 106.0 & - & 105.7 & - \\
\hline 8 & 128.6 & - & 128.3 & - \\
\hline 9 & 103.2 & $6.80(\mathrm{~d}, 1 \mathrm{H}, 2.4)$ & 103.3 & $6.71(\mathrm{~d}, 1 \mathrm{H}, 2.1)$ \\
\hline 10 & 151.8 & - & 152.0 & - \\
\hline 11 & 112.9 & $6.68(\mathrm{dd}, 1 \mathrm{H}, 8.7$ and 2.4$)$ & 113.2 & $6.60(\mathrm{dd}, 1 \mathrm{H}, 8.7$ and 2.1$)$ \\
\hline 12 & 112.8 & $7.17(\mathrm{~d}, 1 \mathrm{H}, 8.7)$ & 113.0 & $7.08(\mathrm{~d}, 1 \mathrm{H}, 8.7)$ \\
\hline 13 & 133.1 & - & 133.6 & - \\
\hline \multirow[t]{2}{*}{14} & 31.6 & $2.28(\mathrm{~m}, 1 \mathrm{H})$ & 28.5 & $2.47(\mathrm{ddd}, 1 \mathrm{H}, 13.8,12.9$ and 4.8$)$ \\
\hline & & $2.14(\mathrm{~m}, 1 \mathrm{H})$ & & $2.16(\mathrm{~m}, 1 \mathrm{H})$ \\
\hline 15 & 31.1 & $1.66(\mathrm{~m}, 1 \mathrm{H})$ & 30.6 & $1.47(\mathrm{~m}, 1 \mathrm{H})$ \\
\hline \multirow[t]{2}{*}{16} & 27.2 & $1.84(\mathrm{~m}, 1 \mathrm{H})$ & 23.6 & $1.47(\mathrm{~m}, 1 \mathrm{H})$ \\
\hline & & $1.64(\mathrm{~m}, 1 \mathrm{H})$ & & $1.96(\mathrm{dd}, 1 \mathrm{H}, 13.8$ and 3.9$)$ \\
\hline 17 & 48.0 & $3.13(\mathrm{t}, 2 \mathrm{H}, 4.2)$ & 59.1 & $\begin{array}{c}3.03-2.94(\mathrm{~m}, 1 \mathrm{H}) \\
3.52(\mathrm{~m}, 1 \mathrm{H})\end{array}$ \\
\hline \multirow[t]{2}{*}{18} & 118.5 & $5.17(\mathrm{dd}, 1 \mathrm{H}, 10.5$ and 1.8$)$ & 118.5 & $5.06(\mathrm{dd}, 1 \mathrm{H}, 10.8$ and 1.8$)$ \\
\hline & & $5.14(\mathrm{~d}, 1 \mathrm{H}, 16.8$ and 1.8$)$ & & $5.04(\mathrm{dd}, 1 \mathrm{H}, 16.8$ and 1.8$)$ \\
\hline 19 & 138.7 & $5.66(\mathrm{ddd}, 1 \mathrm{H}, 16.8,10.5$ and 9.6$)$ & 138.2 & $5.59(\mathrm{ddd}, 1 \mathrm{H}, 16.8,10.5$ and 9.3$)$ \\
\hline 20 & 50.8 & $2.28(\mathrm{~m}, 1 \mathrm{H})$ & 52.3 & $2.07(\mathrm{dd}, 1 \mathrm{H}, 9.3$ and 6.3$)$ \\
\hline \multirow[t]{2}{*}{21} & 64.0 & $3.66(\mathrm{dd}, 1 \mathrm{H}, 11.1$ and 5.9$)$ & 63.8 & $3.51(\mathrm{dd}, 1 \mathrm{H}, 11.1$ and 6.3$)$ \\
\hline & & $3.59(\mathrm{dd}, 1 \mathrm{H}, 11.1$ and 6.3$)$ & & $3.48(\mathrm{dd}, 1 \mathrm{H}, 11.1$ and 6.3$)$ \\
\hline
\end{tabular}

*Number of hydrogens bound to carbon atoms deduced by comparative analyses of $\left\{{ }^{1} \mathrm{H}\right\}$ - and DEPT- ${ }^{13} \mathrm{C}$ NMR spectra. Assignments based on ${ }^{1} \mathrm{H},{ }^{1} \mathrm{H}$ COSY, ${ }^{1} \mathrm{H},{ }^{13} \mathrm{C}$, HMQC and HMBC experiments. 
alkaloids $\mathbf{4}$ and $\mathbf{5}$ showed activity against promastigote forms of L. amazonensis with $\mathrm{IC}_{50}$ values of 16.0 and $40.7 \mu \mathrm{g}$ per $\mathrm{mL}$, respectively.

Table 3. Effect of the extracts and alkaloids isolated from $P$. prunifolia against promastigotes of L. amazonensis and epimastigotes of T. cruzi

\begin{tabular}{lcc}
\hline Extract/Compound & $\begin{array}{c}\text { Promastigote } \\
\text { L. amazonensis }\end{array}$ & $\begin{array}{c}\text { Epimastigote } \\
\text { T. cruzi }\end{array}$ \\
\hline $\mathrm{IC}_{50} /(\mu \mathrm{g}$ per $\mathrm{mL})$ & $\mathrm{IC}_{50} /(\mu \mathrm{g}$ per $\mathrm{mL})$ \\
\hline Root ethanolic extract & $118.6 \pm 4.47$ & $596.0 \pm 56.11$ \\
Branch ethanolic extract & $186.7 \pm 23.09$ & $675.0 \pm 58.0$ \\
$\mathbf{4}$ & $16.0 \pm 5.12$ & $>100$ \\
$\mathbf{5}$ & $40.7 \pm 6.08$ & $>100$ \\
\hline
\end{tabular}

Values represent the mean \pm S.D. of at least three experiments.

\section{Experimental}

Plant material

Fresh material of $P$. prunifolia was collected in September 2007 in the municipality of Goiânia and identified by Piero Delprete of the Federal University of Goiás, at Bosque A. Saint-Hilaire. The plants were found in understory vegetation of seasonal semi-deciduous forest, at $16^{\circ} 36^{\prime} 12^{\prime \prime} \mathrm{S}, 49^{\circ} 15^{\prime} 41^{\prime \prime} \mathrm{W}$ and $850 \mathrm{~m}$ altitude. The voucher specimen, Delprete 10323, was deposited at the Herbarium (UFG) of the Federal University of Goiás, Goiânia. ${ }^{9}$

\section{Extraction and isolation}

The air-dried and powdered branches (149 g) were successively extracted with EtOH. The resulting extract was filtered and concentrated under reduced pressure to yield $17 \mathrm{~g}$. An amount of $12 \mathrm{~g}$ of the resulting ethanolic extract was added to $10 \%$ aq. HOAc $(100 \mathrm{~mL})$. The resulting suspension was incubated at $5{ }^{\circ} \mathrm{C}$ overnight. The suspension was then filtered, and the acidic aqueous phase was extracted with $\mathrm{CHCl}_{3}(3 \times 150 \mathrm{~mL})$. The combined organic layers were treated with $\mathrm{Na}_{2} \mathrm{SO}_{4}$ and filtered, affording a $\mathrm{CHCl}_{3}$ acidic fraction $(0.8 \mathrm{~g}$ - fraction $\mathrm{A})$.

The aqueous layer was adjusted to $\mathrm{pH}$ 8-9 with a saturated aq. $\mathrm{NaHCO}_{3}$ solution, and then again extracted with $\mathrm{CHCl}_{3}(3 \times 150 \mathrm{~mL})$. The combined organic layers were treated with $\mathrm{Na}_{2} \mathrm{SO}_{4}$ and filtered, affording $\mathrm{CHCl}_{3}$ basic fractions ( $0.2 \mathrm{~g}$ - fraction $\mathrm{B})$. This process was repeated using EtOAc as solvent to afford an EtOAc basic fraction (1.35 $\mathrm{g}$ - fraction $\mathrm{C})$.

Compounds 1 (4 mg), 2 (18 mg) and 5 (12 mg) were obtained from fraction $\mathrm{C}(1.0 \mathrm{~g})$ by repeated $\mathrm{CC}$ on silica gel 60 (EtOAc-MeOH- $\mathrm{NH}_{4} \mathrm{OH}$ eluent system in gradient form) and successive purification by preparative TLC on silica gel with EtOAc-MeOH-NH $4 \mathrm{OH}_{4}$ (77:20:3). The fraction $\mathrm{A}$ after successive treatment by $\mathrm{CC}$ on silica gel $60\left(\mathrm{CHCl}_{3}-\mathrm{MeOH}-\mathrm{NH}_{4} \mathrm{OH}\right.$ eluent system in gradient form $)$ and preparative TLC $\left(\mathrm{CHCl}_{3}-\mathrm{MeOH} 75-25\right)$ yielded $6 \mathrm{mg}$ of compound 4 . Compound $3(6.3 \mathrm{mg})$ was isolated by successive fractionation by $\mathrm{CC}$ on silica gel $60\left(\mathrm{CHCl}_{3}-\right.$ $\mathrm{MeOH}$ eluent system in gradient form) from ethanolic extract from branches $(3.88 \mathrm{~g})$.

The crude extract of roots $(9 \mathrm{~g})$ was obtained by extraction with ethanol from $150 \mathrm{~g}$ of powdered roots. Then $5 \mathrm{~g}$ of this ethanolic extract was submitted to the same acid-base treatment described above and yielded $\mathrm{CHCl}_{3}$ acid fraction (0.06 g - fraction D), $\mathrm{CHCl}_{3}$ basic $(0.04 \mathrm{~g}$ - fraction E) and AcOEt basic fraction (0.1g - fraction F). Preparative TLC from fraction $\mathrm{F}$ (61 mg) using $\mathrm{CH}_{2} \mathrm{Cl}_{2}-\mathrm{MeOH}$ (20-1) as eluent system furnished $\mathbf{5}(8.5 \mathrm{mg})$.

\section{General procedures}

IR spectra were recorded with a FTIR Bomem MB100 using $\mathrm{KBr}$ pellets. Optical rotations were obtained with a Bellingham+Stanley Ltd ADP 440. NMR spectra were recorded with a Varian Mercury spectrometer operating at 300.1 $\mathrm{MHz}$ for ${ }^{1} \mathrm{H}$ and at $75.5 \mathrm{MHz}$ for ${ }^{13} \mathrm{C}$. $\mathrm{CD}_{3} \mathrm{OD}$ was used as the solvent, with $\mathrm{Me}_{4} \mathrm{Si}$ (TMS) used as the internal standard. HRMS was performed with a Synapt HDMS spectrometer in positive (or negative) ionisation modes of electrospray ionisation (ESI) (Waters Corporation). TLC was conducted using precoated Kiesegel $60 \mathrm{~F}_{254}$ plates (Merck and M. Nagel). The spray developing reagents used for TLC were $50 \% \mathrm{H}_{2} \mathrm{SO}_{4}$ in $\mathrm{CH}_{3} \mathrm{OH}$ and Dragendorff's reagent.

\section{Antiprotozoal assay ${ }^{17}$}

The effects of the extract and alkaloids were evaluated in promastigotes of L. amazonensis and epimastigotes of T. cruzi (Y strain). For the assay, epimastigote forms of T. cruzi (Y strain) were harvested during the exponential phase of growth, resuspended in liver infusion tryptose broth supplemented with $10 \%$ inactivated foetal bovine serum (Gibco Invitrogen Corporation, New York, NY, USA) and plated on 24-well plates at a concentration of $1 \times 10^{6}$ cells per $\mathrm{mL}$. One millilitre of diluted compound was included in each well and incubated for $96 \mathrm{~h}$ at $28^{\circ} \mathrm{C}$. Cell density was determined by counting the parasites in a hemocytometer chamber (Improved Double Neubauer) under a light microscope. All assays were performed in duplicate on separate occasions. The results were expressed as percentage of inhibition in relation to the control. The $50 \%$ inhibitory concentration $\left(\mathrm{IC}_{50}\right)$ was determined by logarithm regression analysis of the obtained data. 
Parasites were treated with different concentrations $\left(10.0,50.0,100.0,500.0\right.$ and $\left.1000.0 \mu \mathrm{gL}^{-1}\right)$ of crude extract and 1.0, 5.0, 10.0, 50.0 or $100.0 \mu \mathrm{g} \mathrm{mL}^{-1}$ of isolated alkaloids (4 and $\mathbf{5})$.

\section{Supplementary Information}

Supplementary data (NMR, HRMS and IR spectra and spectroscopic data) is available free of charge at http://jbcs.sbq.org.br as PDF file.

\section{Acknowledgments}

We acknowledge the Conselho Nacional de Desenvolvimento Científico e Tecnológico (CNPq), Coordenação de Aperfeiçoamento de Nível Superior (Capes) and Fundação de Apoio à Pesquisa (Funape)-UFG for financial support.

\section{References}

1. Gerlach, S. L.; Burman, R.; Bohlin, L.; Mondal,L.; Goransson, U.; J. Nat. Prod. 2010, 73, 1207.

2. Fragoso, V.; Nascimento, N. C.; Moura, D. J.; Silva, A. C. R.; Richter, M. F.; Saffi, J.; Fett-Neto, A. G.; Toxicol. Vitro 2008, 22, 559 .

3. Both, F. L.; Meneghini, L.; Kerber, V. A.; Henriques, A. T.; Elisabetsky, E.; J. Nat. Prod. 2005, 68, 374.

4. Correa, L. R.; Soares, G. L. G.; Fett-Neto, A. G.; S. Afr. J. Bot. 2008, 74, 583.

5. Khan, M. R.; Kihara, M.; Omoloso, A. D. Fitoterapia 2001, 72,818 .

6. Verota, L.; Pilati, T.; Tato, M.; Elisabetsky, E.; Amador, T. A.; Nunes, D. S.; J. Nat. Prod. 1998, 61, 392.
7. Kerber, V. A.; Passos, C. S.; Verli, H.; Fett-Neto, A. G.; Quirion, J. P.; Henriques, A. T.; J. Nat. Prod. 2008, 71, 697.

8. Solis, P. N.; Ravelo, A. G.; Palenzuela, J. A., Gupta, M. P.; Gonzalez, A.; Phillipson, J. D.; Phytochemistry 1997, 44, 963.

9. Faria, E. O.; Kato, L, Oliveira, C. M. A.; Carvalho, B. G.; Silva, C. C.; Sales, L.; Schuquel, I. T.; Silva-Lacerda, E. P.; Delprete, G. P.; Phytochem. Lett. 2010, 3, 113.

10. Rivas, P.; Cassels, B. K.; Morello, A.; Repetto, Y.; Comp. Biochem.: Physiol. Pharmacol. Toxicol. Endocrinol. 1999, 122, 27.

11. Freiburghaus, F.; Kaminsky, R.; Nkunya, M. H.; Brun, R.; J. Ethnopharmacol. 1996, 55, 1.

12. Tanaka, J. C. A.; Silva, C. C.; Ferreira, I. C. P.; Machado, G. M. C.; Leon, L. L.; de Oliveira, A. J. B.; Phytomedicine 2007, 14, 377.

13. Chan-Bacab, M. J.; Pena-Rodriguez, L. M.; Nat. Prod. Rev. 2001, 18, 674 .

14. Kam, T-S.; Sim, K-M.; Koyano, T.; Komiyama, K.; Phytochemistry 1999, 50, 75.

15. Kan-Fan, C; Zuanazii, J. A.; Quirion J. C.; Husson, H. P.; Henriques, A. T.; Nat. Prod. Lett. 1995, 7, 317.

16. Boughandjioua, N.; Bengaouer, L.; Hotellier, F.; Seguin, E.; Tillequimni, F.; Koch, M.; J. Nat. Prod. 1989, 52, 1107.

17. Haraguchi, S. K.; Silva, A. A.; Vidotti, G. J.; dos Santos, P. V.; Garcia, F. P.; Pedroso, R. B.; Nakamura, C. V.; de Oliveira, C. M. A.; da Silva, C. C.; Molecules 2011, 16, 1166.

Submitted: May 19, 2011

Published online: December 6, 2011

FAPESP has sponsored the publication of this article. 